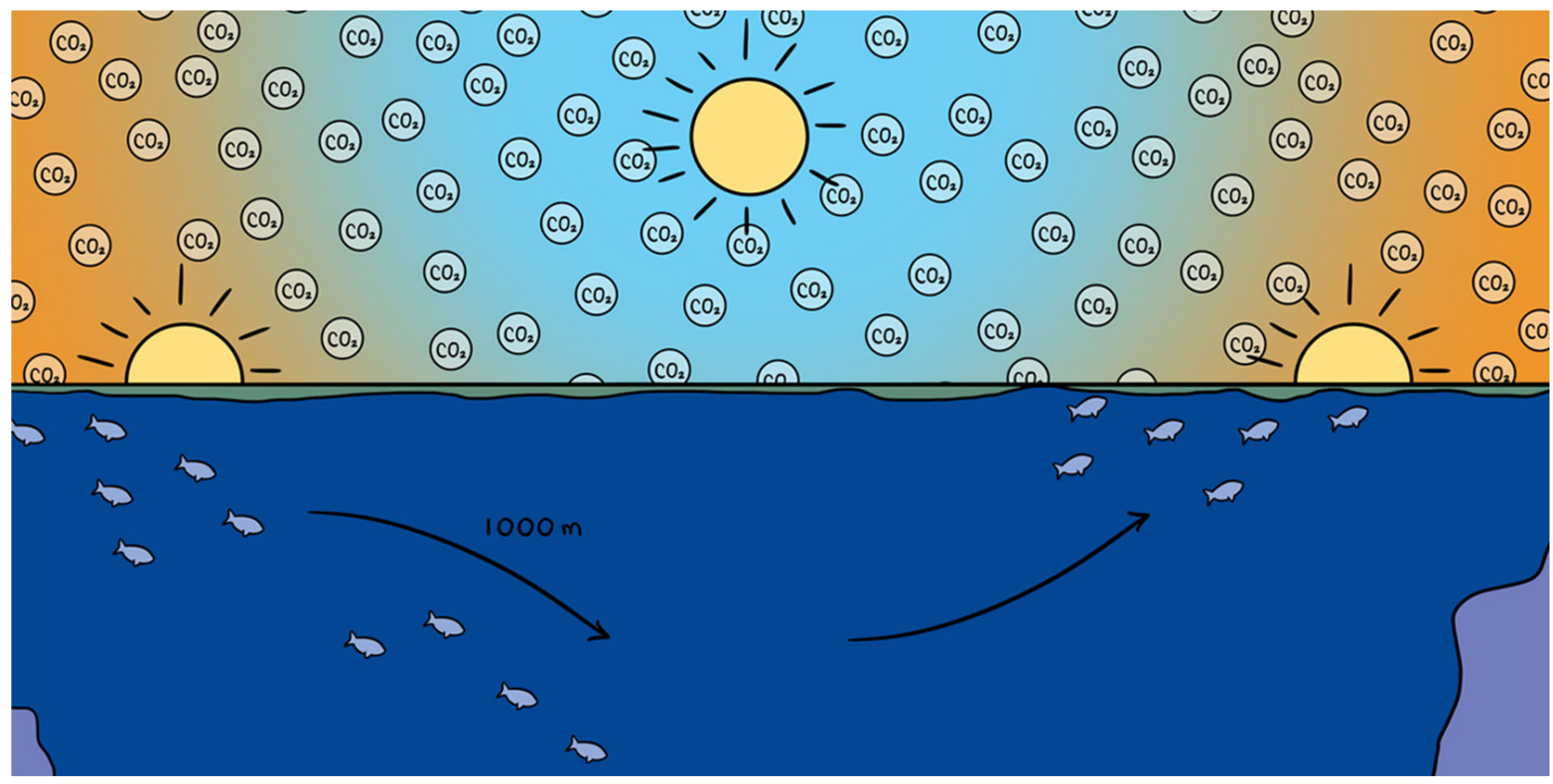

\title{
RED SEA FISHES THAT TRAVEL INTO THE DEEP OCEAN DAILY
}

\section{Maria Ll. Calleja ${ }^{1,2^{*}}$ and Xosé Anxelu G. Morán ${ }^{1}$}

${ }^{1}$ Division of Biological and Environmental Sciences and Engineering, Red Sea Research Center, King Abdullah University of Science and Technology, Thuwal, Saudi Arabia

${ }^{2}$ Department of Climate Geochemistry, Max Plank Institute for Chemistry, Mainz, Germany

\section{YOUNG REVIEWERS:}

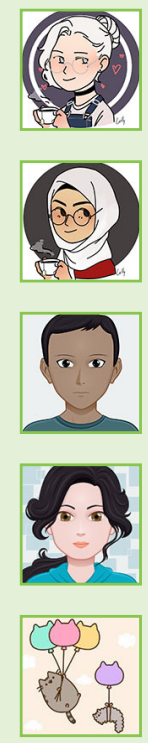

XENIA

AGE: 15
The oceans of the world are extremely important for life on earth. Every day, they produce a large amount of oxygen needed for breathing and, at the same time, they absorb carbon dioxide produced by humans. If we did not have the oceans, this carbon dioxide would build up in the atmosphere much faster than it is accumulating now, leading to faster warming of the earth. In the ocean's sunlit surface, the carbon dioxide is absorbed by small living cells called phytoplankton. Some phytoplankton are consumed by larger organisms and are transferred to the deep ocean. In this article, we investigate the effects of small, fast-swimming fish that feed at the surface during the night and stay in deep waters during the day. In doing this, these fish move carbon from the surface to feed the bacteria living in deep waters. 
PHYTOPLANKTON

Photosynthetic organisms that live in the sunlit surface of the ocean. They take up $\mathrm{CO}_{2}$ from the atmosphere and produce oxygen and organic matter.

\section{PHOTOSYNTHESIS}

Process by which green plants and phytoplankton capture sunlight and turn it into energy. It consumes carbon dioxide and generates oxygen as a by-product

\section{OCEAN CARBON}

CYCLE

Combination of processes that exchange carbon between different reservoirs within the ocean as well as with the atmosphere.

\section{ORGANIC}

Part of or derived from an organism or living entity.

\section{DISSOLVED}

ORGANIC MATTER

(DOM)

Organic material freshly produced by phytoplankton in the surface ocean. DOM serves as food for bacteria in the surface and the deep ocean

\section{WHY ARE THE OCEANS SO IMPORTANT?}

The oceans and seas of our planet produce much of the oxygen we and other organisms breathe. This means that when you take a breath, you are inhaling oxygen that is partly coming from the ocean, whether you live close to the sea or in the middle of a continent! Oxygen comes from the ocean because, near the surface, there are billions of very small organisms, called phytoplankton, that perform photosynthesis, the same way plants do on land. The largest phytoplankton cells are about $1 \mathrm{~mm}$ long. They come in lots of different, beautiful shapes that can be seen under a microscope. During photosynthesis, marine phytoplankton release oxygen and absorb carbon dioxide $\left(\mathrm{CO}_{2}\right)$, using the energy from the sun. This happens in the upper ocean where there is enough sunlight, and this process helps reduce the amount of $\mathrm{CO}_{2}$ in the atmosphere. Without marine phytoplankton, the $\mathrm{CO}_{2}$ that humans produce through the burning of fossil fuels and other industrial activities would build up in the atmosphere even more quickly, and global warming of our planet would speed up. We are very fortunate that $70 \%$ of our planet's surface is covered by the oceans, because they help us mitigate climate change.

\section{A CARBON CYCLE STORY}

What happens to the $\mathrm{CO}_{2}$ once it is absorbed by the organisms in the ocean's surface? Where does it go? The answer is quite complicated: this little molecule is involved in many biological, chemical, and physical reactions, in what we call the ocean carbon cycle. In this article, we will focus on a portion of that cycle connected by animals. During photosynthesis, the phytoplankton transforms $\mathrm{CO}_{2}$ into organic molecules. Organic molecules are substances made of carbon atoms joined together in rings or chains, and other elements, such as hydrogen, oxygen, and nitrogen. For example, amino acids are organic molecules. These molecules are either used by phytoplankton to grow or are eventually released into seawater as waste products. Larger marine organisms eat phytoplankton, and the larger animals are, in turn, eaten by even bigger animals. This way, the organic carbon molecules produced by phytoplankton provide food and energy to all other organisms that make up marine food webs. The waste products of phytoplankton, called dissolved organic matter (DOM), is made of molecules that serve as food for very tiny organisms called bacteria and archaea, which are $<1 \mu \mathrm{m}$ in size (human hair is about $25 \mu \mathrm{m}$ in width!). These tiny organisms live in all depths of the ocean-from the surface to the bottom. Bacteria are the most common organisms on earth and play a very important role in the cycling of carbon in the oceans [1]. 
PROKARYOTES

Single-celled organisms that do not have nuclei. Bacteria are prokaryotes.

\section{DIEL VERTICAL} MIGRATION

Daily synchronized movement of fish and other swimming animals between the surface and the deep layers of the ocean. They spend the day at depth and the night at the surface.

\section{BACTERIA IN THE DEEP OCEAN}

Bacteria and archaea are both prokaryotes, which means that they are single-celled organisms that do not have nuclei. As bacteria are normally more abundant than archaea, we will use the term bacteria to refer to all prokaryotes. We know that bacteria in the ocean's surface thrive by consuming freshly made DOM from phytoplankton, but what do they consume in the deep ocean? Well, they have to manage with the leftover material from the surface that sinks to the deep waters. The leftovers that make it to the deep ocean are not as delicious as the fresh material from the surface. Because of that, for a long time scientists thought that deep bacteria were much less active than surface bacteria. However, now we know that this is not true! Deep bacteria can be as active as surface bacteria [2] and scientists are still investigating how bacterial life in the dark ocean works. We still know very little about it because, as you can imagine, studying water from the deep sea is not that easy.

\section{FISH THAT SWIM BETWEEN THE SURFACE AND THE DEEP OCEAN HELP FEED DEEP BACTERIA}

Modern technologies have provided new information that helps us to better understand the connection between the surface and the deeper layers of the ocean. Scientists have long examined the behavior of schools of small fish that swim up and down between the surface and the deep ocean daily. We call this movement the diel vertical migration (DVM) (Figure 2) [5]. These migrating fish connect the surface and deep waters. Some swim as deep as 1,000 m! They move a huge amount of carbon up and down every day. Like other living things, even their own bodies are made from carbon! We know that these tiny fish are only a few $\mathrm{cm}$ long and like to stay at the surface during the night, where they eat as much phytoplankton and other prey as they can. Then, when the sun is about to rise, they hurry down to the deep sea. They spend the whole day down there, and when the sun is setting, they hurry up to the surface again. We do not know exactly why these fishes perform DVM, but they may do so to avoid being eaten by bigger fishes. They spend the day safely in the deep, where it is always dark, and go up to the surface to feed during the night, when it is also dark. By spending most of their time in the dark, they avoid being seen by the big fish that want to eat them.

\section{HOW DO FISH AND WATER TEMPERATURE AFFECT THE ACTIVITY OF DEEP-SEA BACTERIA?}

We wanted to know whether fish migration might be important for deep sea bacteria. Is there any relationship between the organic carbon that deep sea bacteria consume and the organic carbon that 
Figure 1

Size of bacterial cells at the start and end of the experiment with water from the surface (in green) and water from the fish layer (in orange). Bacteria from the surface did not grow much, but bacteria from the deep fish layer got very large by the end of the experiment. This tells us that the food available for bacteria in the deep water was very nutritious.

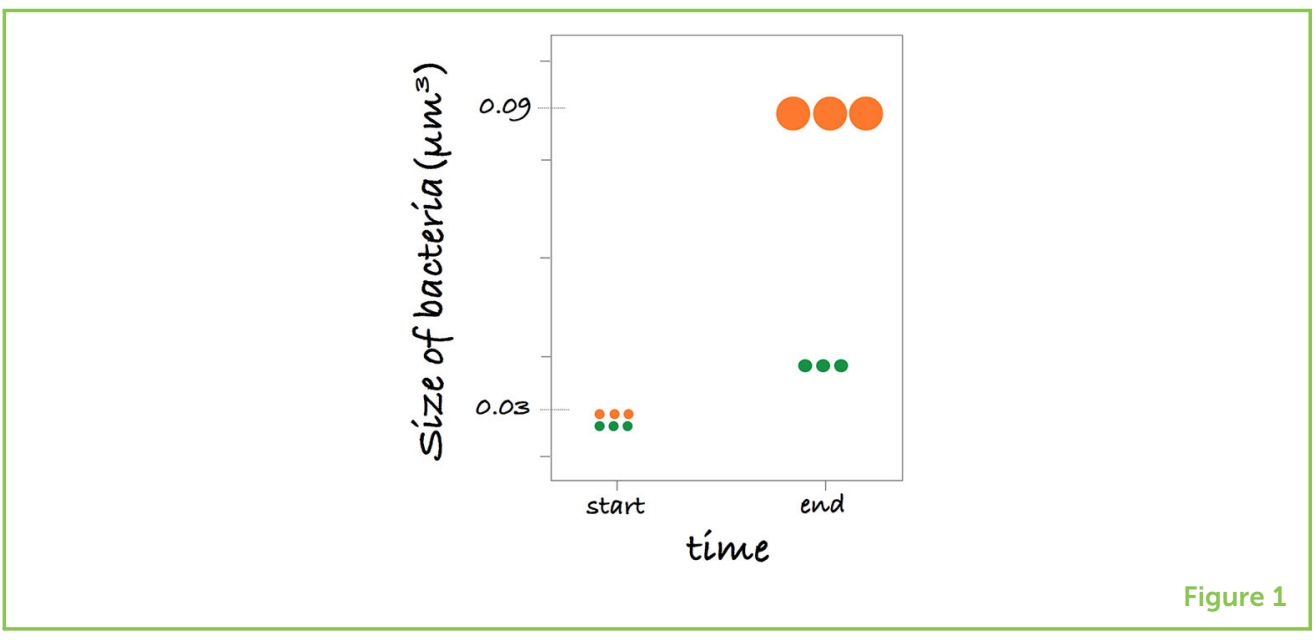

migrating fish provide? To answer this question, we performed an experiment in the Red Sea, one of the warmest seas in the world.

The Red Sea is particularly interesting to us. It can be considered an extreme environment due to its high temperatures, particularly in summer! Deep sea temperatures in other parts of the world are normally between 4 and $8^{\circ} \mathrm{C}$. This is the temperature we have in our fridges ... quite chilly! However, the deep waters of the Red Sea (from $200 \mathrm{~m}$ down to the seafloor) are almost $22^{\circ} \mathrm{C}$. At this temperature, we can go out with short sleeves! The higher the temperature, the more active the bacteria are. Thus, the Red Sea, with a large population of migrating fishes and warm, deep waters, was an ideal place for us to test the response of deep bacteria to fish migration.

\section{AN EXPERIMENT IN THE RED SEA}

In our experiment, we went out at midday and collected water from the depth at which the fish retreat during the day (which we called the fish layer). We knew, from an instrument similar to radar that can detect the presence of fish, that the fish layer was between 500 and $600 \mathrm{~m}$ down. We decided to take water from $550 \mathrm{~m}$ and compare it with surface water from $5 \mathrm{~m}$ down. First, we filtered seawater through membranes with small pores so that only bacteria and DOM were included in the water, and then we brought this water to the lab for further studies. We placed the water samples in an incubator as close as possible to the conditions on site, so that the bacteria had the same number of light hours, dark hours, and the same temperature that they had in the ocean. Bacteria grow quickly, so we monitored changes in the numbers of bacteria and their size during 8 days, taking daily samples from our experimental bottles to measure how the bacteria were growing and how much DOM they were consuming.

We observed that bacteria from the fish layer grew faster than bacteria from the surface. Not only that, but they also got much fatter (Figure 1)! 
Figure 2

The diel vertical migration of skinnycheek lantern fish in the Red Sea. In the first panel, a school of fish are swimming from the surface to the deep waters around sunrise, and they retreat to even deeper waters during the day (second panel). At sunset, they swim back to the surface (third panel), where they feed on phytoplankton during the night (fourth panel). Phytoplankton always stay at the surface, while bacteria and DOM are present both at the surface and deep waters. During the day, surface bacteria consume DOM produced by phytoplankton, and bacteria in deep waters consume DOM provided by the fish. Representation of phytoplankton, bacteria and DOM are a modification from Buchan et al. [3]. Representation of the skinnycheek lanternfish is a fish illustration from Barton Warren

Evermann [4].

\section{SKINNYCHEEK \\ LANTERN FISH}

Example of a fish that migrates vertically in the oceans. It stays in deep water during the day and in surface water during the night. It is present in all the oceans.

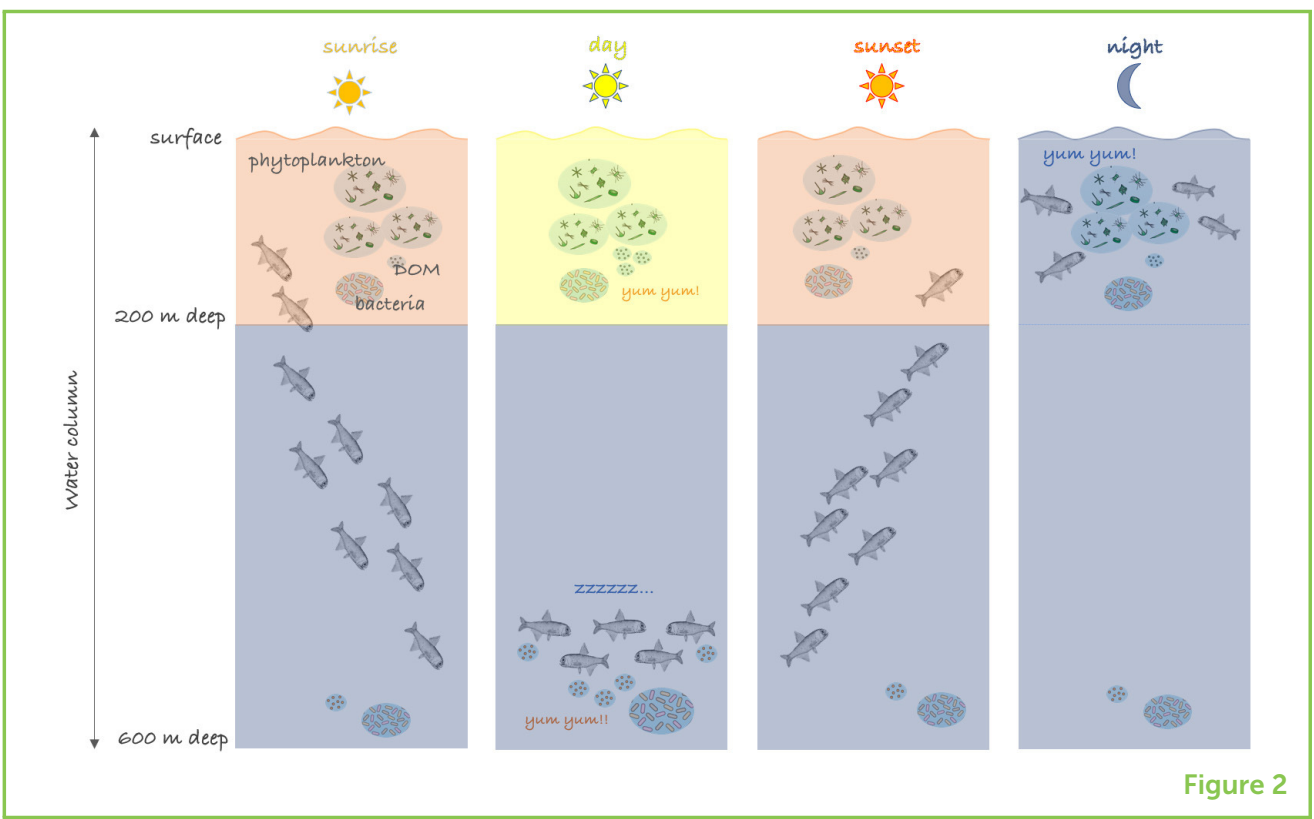

That means that the bacteria found the DOM provided by fish more nutritive than that provided by phytoplankton at the surface. We were very surprised by this result. We believe that when fishes are at the fish layer during the day, they are chilling and digesting their night meal. They relax in the deep waters, pee and poo, and part of this pee and poo is DOM that becomes delicious food for the hungry bacteria of the deep sea. With this experiment, we proved that the vertical migration of fish between the surface and deep waters is not only moving carbon up and down, but it is also providing a source of good food for the deep bacteria!

\section{WHAT WE LEARNED}

Figure 2 shows what we have learned, represented by the diel vertical migration of the skinnycheek lantern fish in the Red Sea. While phytoplankton can only survive in the upper layers where light reaches, bacteria can live everywhere in the ocean. We thought that bacteria in the deep waters were not very active, and that they only consumed the DOM leftovers coming slowly down from the water's surface. However, our experiment suggests that fish migration to deep waters during the day creates a food hotspot for deep bacteria. This had never been seen before.

The next question that comes to our mind is whether this happens in all other oceans. And if so, what are the consequences? Hmm... we still do not know! Every time scientists discover something, new questions arise. There is still so much to learn about the oceans and how carbon is cycled! 


\section{ACKNOWLEDGMENTS}

We would like to thank Nora Gutiérrez Avello (13), Maria de Lluch Calleja Serra (15), as well as the young reviewers and their mentor who read the original draft and provided very helpful feedback to improve it and make it understandable for their age range.

\section{ORIGINAL SOURCE ARTICLE}

Calleja, M. L., Ansari, M. I., Røstad, A., Silva, L., Kaartvedt, S., Irigoien, X., et al. 2018. The mesopelagic scattering layer: a hotspot for heterotrophic prokaryotes in the Red Sea twilight zone. Front. Mar. Sci. 5:259. doi: 10.3389/fmars.2018.00259

\section{REFERENCES}

1. Azam, F., Smith, D. C., Steward, G. F., and Hagström, Å. 1994. Bacteria-organic matter coupling and its significance for oceanica carbon cycling. Microb. Ecol. 28:167-79. doi: 10.1007/BF00166806

2. Arístegui, J., Gasol, J. M., Duarte, C. M., and Herndl, G. J. 2009. Microbial oceanography of the dark ocean's pelagic realm. Limnol. Oceanogr. 54:1501-29. doi: 10.4319/lo.2009.54.5.1501

3. Buchan, A., LeCleir, G. R., Gulvik, C. A., and González, J. M. 2014. Master recyclers: features and functions of bacteria associated with phytoplankton blooms. Nat. Rev. Microbiol. 12:686-98. doi: 10.1038/nrmicro3326

4. Jordan, D. S., and Evermann, B. W. 1902. American Food and Game Fishes: A Popular Account of All the Species Found in America North of the Equator, With Keys for Ready Identification, Life Histories and Methods of Capture. London: Hutchinson and Co.

5. Brierley, A. S. 2014. Diel vertical migration. Curr. Biol. 24:R1074. doi: 10.1016/j.cub.2014.08.054

SUBMITTED: 31 October 2019; ACCEPTED: 29 May 2020; PUBLISHED ONLINE: 09 July 2020.

EDITED BY: Christian Robert Voolstra, University of Konstanz, Germany

CITATION: Calleja ML and Morán XAG (2020) Red Sea Fishes That Travel Into the Deep Ocean Daily. Front. Young Minds 8:85. doi: 10.3389/frym.2020.00085

CONFLICT OF INTEREST: The authors declare that the research was conducted in the absence of any commercial or financial relationships that could be construed as a potential conflict of interest.

COPYRIGHT @ 2020 Calleja and Morán. This is an open-access article distributed under the terms of the Creative Commons Attribution License (CC BY). The use, distribution or reproduction in other forums is permitted, provided the original author(s) and the copyright owner(s) are credited and that the original publication 

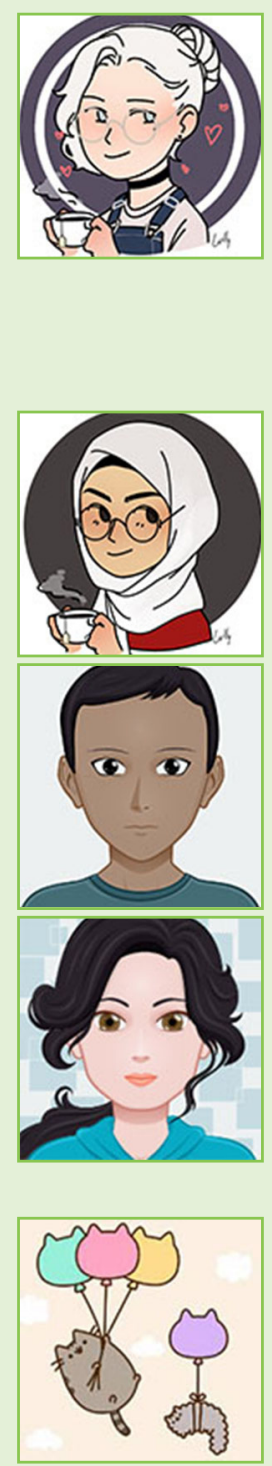

\section{CHLOE, AGE: 15}

Hello! My name is Chloe, I am currently 15 years old. My hobbies include reading, singing, writing and researching. I love to spend hours reading online or with a paperback, depending on my mood, I just love to read. I am currently living with my two Persian cats that love to sing in the night like me and are both lazy like me. In the future, I would like to be a virologist or a genetic scientist, if I do not get to be one of them, I am just gonna be an author ...

\section{HALA, AGE: 15}

Hey! My name is Hala, I am 15 years old and I spend my free time reading and writing short stories. I have an interest in history, politics, economics, and biology. I hope to study journalism in the future, so that I can write articles like these!

\section{HUSSAM, AGE: 15}

My name is Hussam am I am 15 years old. My hobbies include painting, badminton, and photography. My favorite science is biology and I am currently working in a musical production during my after school activities.

\section{SABREEN, AGE: 10}

Bonjour (hello), my name is Sabreen I am 10 years old and I have many passions including science and math. I really like reading and one of my favorite book series is Harry Potter. I also enjoy playing sports (netball, tennis, table tennis, swimming ...) and baking.

\section{XENIA, AGE: 15}

My name is Xenia. I like Science and I think it is awesome to be able to read a scientific article and actually understand what it says. In my spare time I like to read, do gymnastics, and take pictures.

\section{AUTHORS}

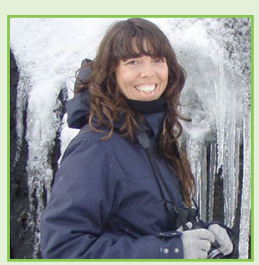

\section{MARIA LL. CALLEJA}

Maria is a marine researcher focused on understanding carbon cycling in the oceans. Her broad interest has brought her to work on systems as different as the tropical and polar ecosystems. Maria's research is focused on the role of microbial organisms in controlling the ocean carbon cycle, and how this is changing in a warming scenario. *maria.calleja@mpic.de

\section{XOSÉ ANXELU G. MORÁN}

Xelu is a professor of biological oceanography and microbial ecology focused on small-sized plankton and its role in the ocean carbon cycle. His interests include phytoplankton-bacteria interactions, variability of photosynthesis and primary 
production, and long-term changes of marine microbial organisms, aimed at understanding the structure and function of microbial food webs and their response to global change. 